\title{
Ecologists attack plans for rare-species act
}

Emma Marris, Washington

Buoyed by their election victory last month, Republican leaders are gearing up for a push to reform the Endangered Species Act in 2005.

But environmental groups and many ecologists - fear that the changes could gut the landmark 1973 law, which protects species' habitats throughout the United States.

At a meeting in San Diego on 2-3 December, governors of the western US states discussed the future of the act. These states have the wildest landscapes and the largest number of endangered species in the country. They also have the strongest political tradition of landowners battling with the government over land-use rules.

The meeting was attended by Richard Pombo (Republican, California), chair of the House resources committee and a key figure in the reform effort. "There is a groundswell that next year will be the year to get something meaningful accomplished," says Pombo's spokesman, Brian Kennedy.

The Endangered Species Act is administered by the Fish and Wildlife Service (FWS). It maintains a list of more than 1,000 threatened and endangered flora and fauna, protects the 'critical habitat' in which they live and, when it can afford to do so, leads recovery efforts such as breeding programmes.

Pombo and Senator Mike Crapo (Republican, Idaho), chairman of a Senate subcommittee on fisheries, wildlife and water, have jurisdiction over the act, and both are planning legislation to amend it next year.

Pombo intends to revive two bills that were passed by his committee this year but never reached the full House for consideration. One would reduce the amount of land designated as critical habitat, and the other would make the scientific process for listing a species more explicit.

Critics say that both moves aim to disarm the act. "It's not as if people go around wantonly protecting species that don't need protection," says Jamie Clark, who ran the FWS from 1997 to 2001 and is now vicepresident of the Washington-based group Defenders of Wildlife. Clark says that the reforms are based on the idea that the science of species conservation is "black and white — which it just isn't".

Crapo's bill is expected to loosen existing deadlines on the designation of species as threatened or endangered and to place restrictions on the designation of critical habitats to protect some species.

Supporters say that the bills will realign the act so that officials can spend more time saving species. "We want the FWS spending less time in courtrooms and more time out in the field with muddy boots," says Kennedy.

But environmental groups are uneasy. "I have grave concerns that the Endangered Species Act is in peril," says Susan Holmes, a lawyer for the pressure group Earthjustice, based in Oakland, California.

Last weekend's meeting coincided with an announcement by the FWS that it has been advised not to list the greater sage grouse (Centrocercus urophasianus) as endangered. Critics regard the FWS's handing of the sage grouse case as evidence that it is softening its enforcement of the species act.

The prospects of the planned reform will depend on how sweeping it attempts to be, political analysts say. Modest reforms will win easy assent, but no one is sure how the new Congress will respond to more extensive changes, such as those backed by some of the western governors. "It's too soon to tell what will happen," says Clark. "People are still working through the politics of it."

The only thing that all sides agree on is that the FWS hasn't got enough money to administer the act properly. The shortfall makes it impossible for the agency to stay on the right side of the existing law, resulting in perpetual legal wrangling over the act. Patrick Parenteau of Vermont Law School in South Royalton, a special counsel for the FWS, says that morale there is at an all-time low. Pombo and his allies promise to work for more funding for the service - if their reforms pass first.

\section{Europe faces call to ban imports of wild birds}

\section{Rex Dalton, San Diego}

More than 200 environmental groups are asking the European Union (EU) to introduce a permanent ban on the importation of wild birds.

The groups plan to file a 12-page declaration with the European Commission by 10 December, requesting the ban in the interests of human health, animal welfare and wildlife conservation.

"When you put the three issues together," says Jamie Gilardi, director of the World Parrot Trust and an organizer of the declaration, the importation of wild birds "makes absolutely no sense".

The trust and some of the other groups have sought a ban on the wild-bird trade for years, but they are hoping that current fears of a bird flu pandemic in humans will lead the commission to implement one.

The EU temporarily banned importation of all birds - including processed poultry and wild species - from nine Asian counties last January after outbreaks of avian flu in southeast Asia. That ban is set to expire on 15 December, but EU officials say it is likely to be extended until 31 March 2005.

As well as being home to the European Commission, Brussels is the centre of Europe's bird trade. Alberto Laddomada, an EU veterinarian who administers animal- health issues there, says that the policy of putting wild birds into quarantine twice once in the shipping nation and once in the receiving nation - is effective at halting the spread of disease. "We can't reduce the risk to zero," he says "but our rules are rigorous and provide a high level of protection."

But campaigners say that Europe's arrangements for enforcing its existing ban are inadequate. And Gilardi says that his trust has uncovered instances in which bird dealers get round the existing system by, for example, falsely claiming that their birds have been quarantined in other countries. "The quarantine facilities in Brussels are a joke," claims Gilardi. 